\title{
The Centrality of Positive Emotions in the Field of Mathematics
}

\author{
By Hava Greensfeld ${ }^{*}$ \\ Ziva Deutsch ${ }^{\dagger}$
}

\begin{abstract}
Mathematics has been perceived as a discipline centered on intellectuality. However, recent studies have found interaction between a variety of emotions and the quality of learning. This qualitative study focused on the characteristics of those who are willing to cope with mathematical challenges and on the emotions evoked by these challenges, and sought to evaluate the potential role of positive emotions in this context. The research was conducted among participants in the Israel International Math Competition for Girls (IIMCG). The participants were 12 of the top finalist competitors in the previous competitions. Research instruments included an in-depth interview and a Math Emotions Measuring Instrument (MEMI), measuring the emotions expressed while coping with the mathematical challenges. Major results indicated the intensity of positive emotions. The positivity ratio was 4:1. Among those emotions, determination and curiosity were dominant, stressing the importance of the motivational factor. The findings indicate the importance of positive emotions and their ability to broaden the thought repertoire and encourage creativity.
\end{abstract}

Keywords: affect, grit positive emotions, math challenges, positivity ratio

\section{Introduction}

The research area investigating the interplay between cognitive and emotional aspects in education is known as affect (Zan, Brown, Evans, \& Hannula, 2006). Seminal work in the 1990s by McLeod (1992) stressed the need to develop a theoretical framework for affect in mathematics education. McLeod represented the affective domain with three constructs: beliefs, attitudes, and emotions. According to McLeod's conceptualization, affect in a broad sense in mathematics education is positioned along a spectrum ranging from the left, cognitive end - of stability and coolness (beliefs), to the right, affective end - of fluidity and intensity (emotions). Attitudes are often seen as an intermediary construct: more stable than emotions, but less stable than beliefs and/or values (a $4^{\text {th }}$ construct added by DeBellis \& Goldin, 1997).

Many researchers have studied how certain distinct yet interrelated variables, such as background, motivation, and social support, can serve to explain differences in student attitudes towards mathematics. Additionally, those researchers worked to reach an understanding of the defining characteristics of these attitudes in the school environment (Mata, Monteiro, \& Peixoto, 2012). Their findings indicate that different approaches toward

\footnotetext{
${ }^{*}$ Head of Research Unit, Michlala, Jerusalem College, Israel.

${ }^{\dagger}$ Head of Math Department, Michlala, Jerusalem College, Israel.
} 
mathematics are a function of many interrelated variables, as they relate to students, families, and schools. Among student variables, several researchers have indicated that attitudes are a key factor to be taken into account when attempting to understand and explain variability in student performance in math (e.g., Mohamed \& Waheed, 2011).

It has long been understood that attitudes towards school mathematics are rooted in childhood experience, since it is precisely during the formative years of schooling that children develop many of their beliefs and attitudes towards mathematics. Family members, especially parents, were found to be central influences on a child's developing view of mathematics. In a review of the impact of family involvement on childhood education and mathematics achievement outcomes, it was found that children benefit when parents and family members get involved in their learning and development (van Voorhis, Maier, Epstein, \& Lloyd, 2013). This claim was supported by decades of research that suggests that family engagement is positively linked to children's outcomes in preschool, kindergarten, and early elementary grades (e.g., Fan \& Chen, 2001; Soni \& Kumari, 2015).

In addition to the substantial role played by parents, it was found that teachers of mathematics are also a major influential factor (e.g., Domino, 2009). Teachers influenced students' understanding and attitudes toward mathematics through the teaching methods they employed, by ascertaining that students understood the material, and through their personalities. In particular, students reported that they understood and enjoyed mathematics when their teachers delivered fun and interesting lessons, actively engaged students in the classroom, highlighted connections in the material relevant to the students' everyday lives, taught at a relatively slow pace, assisted students outside of the classroom, cared about their students, and were enthusiastic about teaching mathematics and, more generally, the subject of mathematics as a whole.

In the present study, we emphasized the right side of the spectrum of affect: emotions. Recently, many researchers have found an interaction between a variety of emotions and learning quality (e.g., Linnenbrink, 2006; Pekrun, Goetz, Titz, \& Perry, 2002). Emotion research has presented different approaches to studying this field, and there is no consensus as to what the concept of emotions includes (Linnenbrink-Garcia \& Pekrun, 2011). Nevertheless, regarding certain aspects of the concept, it is agreed that emotions are expressed in individual contexts, involve reactions, and play a decisive role in human behaviors (Buck, 1999; Mandler, 1989). Emotions also fulfill a central role in the students' involvement and achievements in the learning process (Linnenbrink-Garcia \& Pekrun, 2011).

Previously, mathematics education was perceived as an intellectually centralized field with emotions taking a minimal role. Most research in this field focused on fear and anxiety (e.g., Weiner, 1985), with little attention to other emotions. This approach has now changed and for more than a decade, researchers have shown interest in the expression of a variety of emotions in mathematics education (e.g., Hannula, 2002; 2012; Pekrun, Goetz, Titz, \& Perry, 2002), with emphasis particularly on positive emotions. Additional 
studies on mathematics education found a relationship between academic selfperception and students' learning experience (e.g., Goetz, Frenzel, Hall, \& Pekrun, 2008). A positive correlation was found also between pleasant emotions such as enjoyment and pride and academic self-perception opposed to negative emotions such as anger and anxiety (Frenzel, Pekrun, \& Goetz, 2007).

\section{The Role of Positive Emotions}

The positive psychology approach has focused lately on factors that cause a sense of well-being. Positive emotions were found to play a balancing role between those factors and negative emotions. It was claimed that at moments of experiencing positive emotions such as happiness and interest, people stop experiencing negative emotions such as anxiety and sadness. This tipping of the balance has an effect on their subjective judgment and well-being (Diener, Sandvik, \& Pavot, 1991; Pavot \& Diener, 2013).

Dr. Barbara Fredickson of Stanford University is a groundbreaking researcher in this field. She claimed (e.g., Fredrickson, 2001; 2013) that positive emotions are not only a sign of flourishing, but create and generate a sense of flourishing. According to Fredrickson's broaden-and-build theory of positive emotions, positive emotions momentarily broaden the thought repertoire and work to increase attention span, as well as people's awareness and motivation to move beyond their basic needs (see Fredrickson \& Branigan, 2005). In this building process, the resources constitute a reserve for later use, improving the chances of better coping with the situation. Thus, through experiencing positive emotions, individuals undergo self-change and become more creative, knowledgeable, flexible, socially involved, and healthy.

\section{Emotion-measuring Instruments}

Emotions have been conceptualized in both discrete and dimensional terms. Dimensional perspectives suggest that emotional states are organized by underlying factors such as valence, arousal, and motivational state (Barrett \& Russell, 1998; Mauss \& Robinson, 2009; Russell, 1980).

Sorting emotions into groups (Buck, 1999; Ortony \& Turner, 1990; Parrott, 2001) was the basis for developing several emotion-measuring instruments. Buck (1999) claimed that emotions can be measured using three types of instruments:

a. physiological (breathing rate and blood pressure changes),

b. observed facial expressions,

c. self-report about subjectively experienced emotions.

In the field of mathematics education, the first instrument to be developed consisted of self-report questionnaires to examine fear and anxiety. Later (Frenzel, Pekrun, \& Goetz, 2007; Pekrun, Goetz, Titz, \& Perry, 2002), measurement instruments were developed for identifying the positive and negative emotions expressed when learning mathematics. The self-report 
Academic Emotions Questionnaire (AEQ) measures nine emotions. Hannula (2006; 2012) suggested that even though self-report questionnaires are still the dominant instrument in mathematics education research, it is worthwhile using additional instruments in parallel, such as observations and interviews.

In this paper, which presents the qualitative part of a mixed-methods study (Creswell, 2013), 2 instruments were used to examine emotional aspects when coping with mathematical challenges. Unlike other qualitative studies (e.g., Di Martino \& Zan, 2010; 2011; Hannula, 2006; 2012) which focused on mathematics education in school, the participants in our study had coped successfully with a mathematical challenge: a mathematical thinking problemsolving competition.

\section{Mathematics Competitions}

In a competition, several participants are required to perform the same tasks and are ranked according to their achievements. Taylor (2009) claimed that the term "competition" does not precisely reflect the nature of most mathematics competitions. In addition to competition among participants, they involve the individuals' competing with the challenging problems they face. Indeed, in mathematics competitions, the competitors struggle with the problems presented, and their achievements are compared with other competitors only at the end of the process.

The Israel International Math Competition for Girls (IIMCG) is a mathematical thinking problem-solving competition for Jewish girls aged 15 to 20. So far it has been held six times and has gradually increased in scope. Nearly 8,000 girls from around the world participated in the three rounds of the sixth competition in 2014. The final round took place in Jerusalem.

This type of competitive situation, of climactic moments, arouses increasingly intense emotions and therefore enables disclosure of a variety of emotions (Cooke, Kavussanu, Mcintyre, \& Ring, 2013; Lazarus, 2000; Martinent, Campo, \& Ferrand, 2012; Muñoz-Merino, Molina, MuñozOrganero, \& Kloos, 2014).

Our study has the potential to shed new light on the connection between mathematics and emotions and evaluates the importance of positive emotions in this context.

\section{Research Question}

What can be learned from interviews with several top competitors from the Israel International Math Competition for Girls, regarding the dominant emotions that are experienced while coping with a mathematical challenge, and the position of positive emotions in this context? 


\section{Secondary Questions}

1. What are the characteristics of those willing to cope with mathematical challenges (such as where they live, their parents' occupations, their childhood experiences, and their perceptions of the role of the math teachers)?

2. Which positive and negative emotions are involved in the willingness to cope with mathematical challenges?

3. How do the research participants perceive the role of the positive emotions involved in this context?

\section{Method}

\section{Research Type}

The present study was qualitative, based on in-depth semi-structured interviews including a self-report instrument to measure emotions experienced by each participant while coping with a mathematical challenge.

\section{Participants}

The study population was unique: 12 competitors were chosen from the 60 top -10 finalists in the six IIMCG competitions held to date. The consideration that guided us in choosing the 12 interviewees was the willingness to portray as wide a variety of prototypes as possible: Thus, participants were chosen to represent a wide variety of competitors (Johnson, 2002; Ryen, 2002), in terms of location (population centers and outlying areas, urban and rural settlements, from Israel and from abroad), age (ages 15 - 20), and occupation (high school students, volunteers enrolled in the National Service program, students of higher education). Nevertheless, given that the main research instrument consisted of in-depth interviews necessitating face-to-face meetings, research participants were also chosen in accordance with the constraints imposed by their place of residence. Thus, for example, we were forced to forgo interviews with the IIMCG competitors who live in Australia. Thus, the participants were chosen to represent a variety of competitors (Johnson, 2002) in terms of places of residence, age, and occupation, as presented in Table 1. 
Table 1. Characteristics of Interviewed Competitors $(\mathrm{N}=12)$

\begin{tabular}{|c|c|c|c|c|c|c|}
\hline Interviewee & Country & $\begin{array}{c}\text { Residential } \\
\text { Environment }\end{array}$ & Age & \multicolumn{2}{|c|}{ Parents' occupation } & Remarks \\
\hline & & & & Mother & Father & \\
\hline Sandra & USA & $\begin{array}{l}\text { Brookline } \\
\text { Suburb of } \\
\text { Boston, } \\
\text { Massachusetts }\end{array}$ & 15 & $\begin{array}{l}\text { Computer } \\
\text { professional, currently } \\
\text { homemaker }\end{array}$ & $\begin{array}{l}\text { Senior computer } \\
\text { professional }\end{array}$ & \\
\hline Gail & Israel & $\begin{array}{l}\text { Outlying rural } \\
\text { community }\end{array}$ & 17 & $\begin{array}{l}\text { Lawyer by profession, } \\
\text { currently homemaker }\end{array}$ & $\begin{array}{l}\text { Manager of financial } \\
\text { company }\end{array}$ & $\begin{array}{l}\text { Family immigrated from } \\
\text { Australia (born in Israel) } \\
\text { Liberal home }\end{array}$ \\
\hline Sue & USA & $\begin{array}{l}\text { Lawrence, New } \\
\text { York }\end{array}$ & 17 & Homemaker & Gynecologist & $\begin{array}{l}\text { Grandfather mathematician } \\
\text { Started writing math quiz } \\
\text { column for Jewish } \\
\text { newspaper }\end{array}$ \\
\hline Emma & UK & Manchester & 17 & Optician & Optician & $\begin{array}{l}\text { Won first place in } 2014 \\
\text { competition } \\
\text { Specializing in Math, } \\
\text { Physics, Chemistry, and } \\
\text { Further Math }\end{array}$ \\
\hline Debbie & Israel & $\begin{array}{l}\text { Kibbutz in the } \\
\text { South }\end{array}$ & 17 & Medical doctor & Medical doctor & $\begin{array}{l}\text { Grandfather doctor of } \\
\text { mathematics } \\
\text { Spent two years of childhood } \\
\text { in Toronto studying at } \\
\text { university for bachelor's } \\
\text { degree in math }\end{array}$ \\
\hline
\end{tabular}




\begin{tabular}{|c|c|c|c|c|c|c|}
\hline Lizzy & USA & $\begin{array}{l}\text { Small town in } \\
\text { New Jersey }\end{array}$ & 17 & Engineer & Radiologist & $\begin{array}{l}\text { Studies calculus with two } \\
\text { boys }\end{array}$ \\
\hline Vivian & Israel & Jerusalem & 17 & $\begin{array}{l}\text { Senior citizens' home } \\
\text { director }\end{array}$ & $\begin{array}{l}\text { Computer professional, } \\
\text { musician (violinist) }\end{array}$ & \\
\hline Ella & Israel & $\begin{array}{l}\text { Rural } \\
\text { community in } \\
\text { central Israel }\end{array}$ & 18 & Homemaker & Electronic engineer & $\begin{array}{l}\text { Participated in sports } \\
\text { competitions from an early } \\
\text { age } \\
\text { Now in National Service }\end{array}$ \\
\hline Rachel & Israel & Tel Aviv & 18 & $\begin{array}{l}\text { Hi-tech company } \\
\text { manager }\end{array}$ & $\begin{array}{l}\text { Senior electrical } \\
\text { engineer }\end{array}$ & $\begin{array}{l}\text { Awaiting enlistment in an } \\
\text { academic track in the army, } \\
3^{\text {rd }} \text { year in math program for } \\
\text { outstanding students in } \\
\text { preparation for a bachelor's } \\
\text { degree }\end{array}$ \\
\hline Shari & Israel & $\begin{array}{l}\text { Outlying rural } \\
\text { community }\end{array}$ & 18 & Physics teacher & Hi-tech professional & $\begin{array}{l}\text { Plays violin and piano } \\
\text { Completed math } \\
\text { matriculation in } 10^{\text {th }} \text { grade in } \\
\text { gifted students program } \\
\text { Now in National Service }\end{array}$ \\
\hline Sophia & Israel & $\begin{array}{l}\text { City in central } \\
\text { Israel }\end{array}$ & 19 & Accountant & Engineer & \\
\hline Ruth & Israel & $\begin{array}{l}\text { City in outlying } \\
\text { area }\end{array}$ & 22 & Post office clerk & Carpenter & \\
\hline
\end{tabular}


As apparent in the table, most of the participants came from families with academic backgrounds, whose parents' occupations tended toward the scientific fields. Three grandfathers were mathematicians. One family differed conspicuously in parental occupations: the father was a carpenter and the mother - a post office clerk. Since the competition was held in Israel, there was high representation of Israeli participants.

\section{Research Instruments}

a. An in-depth interview (1.5 to 2 hours) in which the participant was asked about three main areas: her math-related history, her willingness to cope with mathematical challenges, and her stories of success and failure with them. The following are a few examples of the questions that were represented in the interview:

Try to recall a childhood memory connected to math, and describe it as best you can; What feelings does that memory arouse in you?; What qualities or abilities do you think you have that make you open to math challenges and willing to contend with them?; Tell us about a math challenge that you feel you contended with successfully; Try to identify some of the feelings you had at different points while you contended with that challenge; What role do you think positive emotions play in dealing with math?; What role do you think negative emotions play in dealing with math?

b. MEMI (Math Emotions Measuring Instrument) - a self-report instrument measuring interviewees' positive and negative emotions expressed while coping with a mathematical challenge. Similar to the Positive and Negative Affect Schedule (Watson, Clark, \& Tellegen, 1988) and the AEO (Pekrun Goetz, Titz, \& Perry, 2002), MEMI was designed to measure positive and negative emotions to appraise emotional state. It consisted of 30 words describing different emotions that might be experienced while coping with mathematical challenges; 15 for positive and 15 for negative emotions. According to the dimensional perspectives, when selecting the emotions, we also took into consideration their activation dimension (Barrett \& Russell, 1998).

The axis of activation-deactivation represents the level of awareness that a person feels during the expression of a given emotion. Both positive and negative emotions can be expressed at either high levels of activation or low levels (deactivation). For example, the emotions of confinement and hatred reflect high activation, while the emotions of relaxation and sadness reflect emotions of deactivation.

The final list comprised of nine positive-active emotions (e.g., determined), six positive-deactive emotions (e.g., relaxed), seven negativeactive emotions (e.g., angry), and eight negative-deactive emotions (e.g., sad). 
Participants were asked to indicate the intensity of each emotion while coping with mathematical challenges on an 8-point scale from $0=$ Not Relevant, $1=$ Very Slightly, to 7= Extremely. Each interviewee was then asked to choose the five emotions most frequently experienced in this context. This instrument for measuring emotions was used previously in our quantitative study ( $\alpha=.840$ ) (Deutsch \& Greensfeld, 2016) and was introduced to the interviewee in the present research, after establishing an atmosphere of trust between her and the interviewer. Once the interviewees completed the self-report instrument, an extensive discussion helped us understand the interviewees' conceptualization of their emotional experience.

The transcription of the 12 interviews served as a text for content analysis, which was conducted in several stages of open and axial coding (Corbin \& Strauss (2007).

\section{Results}

The interviews were conducted with 12 young women from different countries, each with unique math stories and experiences. They were conducted either in Hebrew or in English, in accordance with the interviewees' preferences. Significant differences were found in the participants' ability to connect to the research and in their openness to the topic of math and emotions ("I've never thought about how I felt when doing math. There is emotions, but in math, you connect less to emotions", Vivian) and sometimes in their ability to explain their emotions verbally. Most participants had never thought about the math-emotions relationship ("These questions are strange, I've never thought deeply about the relationship between math and emotion. This is the first time", Emma). Overall, about two thirds of the interviewees communicated reasonably well, and despite having never paid attention to the subject, showed interest and cooperation. Two participants were more inhibited about discussing their emotions, and two others had difficulty in presenting their emotions and even had reservations about some of the questions.

Content analysis (Corbin \& Strauss, 2007) of the interviews exposed several characteristics that recurred with most participants, with the most prominent presented below.

\section{Childhood Experience of Math}

Childhood experiences were shown to be central to a positive attitude toward math. They included home discussions of math puzzles, quizzes, and thinking games, which were mentioned as unforgettable emotional experiences and as creating family belonging. Participants associated these experiences as dominant in family situations, such as the weekly gathering around the "Sabbath table". The childhood experience component appeared in almost all the interviewees, as represented in the following quotes:

"I remember my dad asking us lots of puzzles as children, like measuring 
water puzzles [...] It was a kind of game. My mom is also a teacher; there was always that kind of talk at home [...] When sitting together on the Sabbath, we throw out a puzzle." (Shari)

"I remember we always had this thing at home about extra-curricular activities and quizzes. And there was always the bee traveling between the trains and the Möbius strip [...] and then I got to the stage when I could take part in the doing. That was great fun. I suddenly felt this wow, I always felt part of the family, but now I feel even more connected, I am really part of this family." (Rachel)

"Around the family gatherings, Mom used to give us questions and puzzles. That was very nice, everyone together, solving and thinking together. She gave us puzzles from a calendar that presented a question a day. It created a pleasant, competitive atmosphere." (Sue)

Mathematical discourse in childhood often created not only a sense of belonging but also a family language, a code of speech that an outsider would not understand.

"We speak a kind of math language at home."It's reasonable that [...] from this we can derive [...] that's a language for all intents and purposes"." (Rachel)

In many cases, the family discourse linked the math topics to life, making theoretical concepts relevant:

"My dad used to give us real-life questions that depended on math, like: how long does it take to get to Antarctica?" (Sandra)

Childhood exposure to math through a family experience is sometimes described as a source of self-confidence in the present:

"I feel confident with math problems. I don't give up. I tell myself I can do it. What my mom gave me in childhood really helped me. I always felt ahead of everyone in the 'game'". (Sue)

In the participants' stories, the influence of the family environmentparents, siblings, and grandparents-are central and significant, and the participants frequently mentioned family figures as influencing them and their long-term attitude toward math.

\section{The Teacher Figure}

It is interesting to compare the influence of family figures with that of the teachers' throughout. Some participants mentioned inspirational teachers: 
"I had several significant teachers: A $2^{\text {nd }}$ grade teacher encouraged me with logical thinking and with looking at math in a certain way, so I started to think math was interesting [...] A history teacher saw my ability and challenged me with geometry problems to whet my curiosity." (Lizzy)

Sometimes, however, the teachers were presented in a less complimentary ways, with emphasis on "at least they didn't bother me":

"The teacher used to tease me about not coming to class that much. I think if I can understand the lesson in 10 minutes, it's a shame to be there, and the teacher understood that." (Gail)

"I liked math regardless of the teachers. My parents inspired me more than the teachers. At least my teachers didn't destroy my love of math." (Vivian)

Some teachers were described as "anti-figures", who suppressed the participants' unique and slightly unusual thinking:

"In high school, I had teachers who held me back: 'Don't run ahead, slow down'." (Sophia)

"One of my high school teachers forced us to use a calculator. She was too slow and wanted to move me to a lower level group." (Ruth)

\section{Coping with Mathematical Challenges as an Emotion-evoking Experience}

During the interview, and before introducing MEMI (the emotion measuring instrument), we asked the participants a few open questions about their experiences of coping with mathematical challenges. Different emotions arose in their descriptions, some recurring among most or even all the participants. The most prominent were determination and curiosity.

\section{Determination and Curiosity}

"With every challenging mathematical problem, I won't give up until I've finished [...] Stubbornness, curiosity, determination, wisdom, precision; those skills enable me to cope with mathematical challenges [...] If there's a puzzle, I'll want to solve it. It's for me." (Ruth)

"I tried for an International Math Olympiad. I didn't get in, but stayed in the exam till the end. I didn't give up [...] I need to finish things [...] The willingness to cope with math doesn't depend on environmental expectations." (Shari)

"When I have a mathematical challenge it's like solving a puzzle [...], I'll sit there until the middle of the night and won't go to sleep until I've 
solved it. It's satisfying. I have to succeed, even if it takes time. I can think about it during the night [...] I am motivated to solve problems. I hate looking at the solutions. I want to solve them myself!" (Gail)

"I love the moment of discovery, of succeeding. I'm not stubborn but if something interests me, I'll invest time to find the answer [...] I have this inner drive to try and try till I succeed." (Sophia)

Being Creative. Besides determination and persistence, enjoyment and happiness were conspicuous in most of the interviewees:

"Wow, what fun, this is cool. Strategy games are exciting [...] I love doing something different." (Sophia)

"I love math, I live math. It's my hobby." (Ruth).

These emotions were expressed more intensely with challenges that demanded a creative solution. Most of the participants expressed their need to solve certain problems specifically in a creative way. The creative way of solving a certain problem gave the solvers the feeling that the problems were "theirs", as illustrated in the following quotes:

"Wow. I succeeded. It's great to solve creatively. It's fun and satisfying." (Shari)

"Finding a creative solution makes me feel happy that I managed to solve the question in a different way. I like originality, finding ways that the teacher hasn't thought of." (Vivian)

"If you think in a cooler way, it's better. The goal isn't just the answer but also the method too. When you do something differently, it's more special." (Ella)

"When I solve a problem creatively, I become more involved and it becomes more personal to me. Because I feel I added something of myself to the solution." (Lizzy)

An additional point is emphasized in their expressions: the enjoyment and happiness of "solving by oneself", as described by Gail:

"I am motivated to solve problems. I hate looking at the solutions. I want to solve them myself."

\section{The MEMI}

The emotions that were prominent in the first part of the interview were found to be so in the MEMI as well. The participants were first asked to 
indicate the intensity (from 0 to 7 ) at which they experienced each of the 30 emotions on the list while coping with mathematical challenges.

In total, all the participants scored higher on the positive than on the negative emotions. A summation of data regarding the intensity of each of the 30 emotions among the 12 participants, showed an overall score of 808 for all 15 positive emotions as opposed to 158 for all 15 negative emotions.

These findings are consistent with those of the quantitative portion of our research $(\mathrm{N}=207)$, whereby the sum of the intensity score of positive emotions expressed while coping with a mathematical challenge was around four times greater than the sum of the intensity score of the negative emotions (Deutsch \& Greensfeld, 2016).

An especially prominent datum in the present qualitative study was that three out of the 12 participants marked 0 for all the 15 negative emotions, meaning that they had difficulty identifying any negative emotion that characterized their experience of coping with mathematical challenges.

Later on, those same interviewees emphasized that they do not experience negative emotions in connection to coping with a mathematical challenge. For them, it is perceived as an experience that arouses purely positive emotions.

Besides scoring each of the 30 emotions, the participants were asked to choose the five emotions that they experienced most frequently during mathematical challenges. The most frequent emotions were (in descending order): determined, curious, pleased, riveted, enthusiastic, and relaxed-6 positive emotions. Of these, four were highly activating and two (pleased and relaxed) were deactivating. Table 2 presents the emotions mentioned along with their frequency and their intensity score.

Table 2. Frequency of Chosen Positive Emotions (of the Five Most Frequent)

\begin{tabular}{|l|r|r|r|c|}
\hline Emotion & Valence & $\begin{array}{c}\text { Activation / } \\
\text { Deactivation }\end{array}$ & $\begin{array}{c}\text { Frequency } \\
\text { (No. of participants wh } \\
\text { included the emotion in } \\
\text { their choice of the five } \\
\text { most frequent) }\end{array}$ & $\begin{array}{c}\text { Sum of the } \\
\text { Intensity Scores }\end{array}$ \\
\hline Determined & + & active & 11 & 68 \\
\hline Curious & + & active & 11 & 65 \\
\hline Pleased & + & deactive & 7 & 44 \\
\hline Riveted & + & active & 5 & 34 \\
\hline Enthusiastic & + & active & 4 & 17 \\
\hline Relaxed & + & deactive & 3 & 13 \\
\hline In Love & + & active & 2 & 12 \\
\hline Happy & + & active & 2 & 11 \\
\hline Competitive & + & active & 2 & 10 \\
\hline Harmonious & + & deactive & 2 & 6 \\
\hline Excited & + & active & 2 & 4 \\
\hline Exhausted & - & deactive & 1 & 4 \\
\hline Brilliant & + & deactive & 1 & \\
\hline Apprehensive & - & deactive & 1 & \\
\hline Tense & - & active & 1 & \\
\hline
\end{tabular}

It can be seen from Table 2 that 11 out of the 12 participants chose 
"determined" and "curious" in the top five for frequency. It is noteworthy that 15 out of the 30 emotions were not chosen at all. Only 15 emotions were chosen: 12 positive and three negative.

In their responses to questions about frequent emotions in daily life, the five emotions mentioned as most frequent during mathematical challenges were evidently frequent in daily life as well, but were conspicuously more intense while coping with mathematical challenges:

"Emotions in math are stronger than in other fields." (Shari)

"I think that all the emotions are there in daily life, but they are more intense in math. When you're pleased while doing math, it's more extreme." (Rachel.

In addition, emotions unique to mathematics were found: "I'm usually content. I'm determined. But in day-to-day life, I'm not riveted. That's an emotion unique to math. It's not there so much in daily life" (Ella); "In everyday life, I'm not always happy, but with math-yes!" (Vivian)

\section{Discussion}

Similar to contemporary studies (e.g., Di Martino \& Zan, 2010; 2011), varied research instruments (both quantitative and qualitative) were included in the present study, enabling a deep understanding of the emotions involved in coping with mathematical challenges. These emotions were found to be anchored and nourished by previous childhood experiences, which created a positive view of math. The role of adult family members was found to be significant in this context, along with the role of math teachers. These findings are consistent with current findings that indicate the importance of developing positive views of mathematics particularly during childhood. These views promote willingness to engage in mathematical challenges later on (Singh, Granville, \& Dika, 2002; Soni \& Kumari, 2015; van Voorhis et al., 2013). Hence, Rösken, Hannula, and Pehkonen (2011), listed family encouragement as a factor in the seven-factor model of students' self-perception as learners of mathematics. Our findings are consistent with the quantitative portion of this study that showed, through hierarchical analysis using structural equation modeling, that motivation-related variables are the main predictors of attitudes towards mathematics and that teachers and the social support of peers are also highly significant in understanding these attitudes (Mata, Monteiro, \& Peixoto, 2012).

The present study exposed the centrality of positive emotions in coping with mathematical challenges, in both the quantitative and qualitative analysis. When weighting the emotions by intensity, the positive emotions score was five times greater than the weighted score of the negative emotions. Fredrickson (2013) pointed to the role of positive emotions and coined the term 
"positivity ratio", which is the ratio between the positive and negative emotions experienced. She claimed that below a ratio of 3:1 (3 positive emotions to each negative emotion), people are nourished by negativity, have a tendency to regression, and become lethargic. Above this ratio, people are nourished by positivity, and have an elevating experience of achievement. The mean positivity ratio among the present study participants was, as mentioned, 5:1. The high positivity ratio was reflected in the interviews, in which the participants extolled the creative aspect and its importance in coping with mathematical challenges, and described it, like in Fredrickson's theory, as a nurturing force and a factor in their ability to thrive. Actually leading researchers in the area of positive psychology agree that positively deviant performances yield more creativeness, better productivity, better performance, and flourishing workplaces (Fredrickson \& Losada, 2005).

In a discussion about emotional intensity, the participants claimed that although the emotions mentioned are common in daily life, their intensity is greatly increased while dealing with mathematical challenges. This finding is consistent with studies that focused on negative emotions such as anxiety, which claim that this negative emotion intensifies specifically when doing math (Weiner, 1985). The findings regarding emotion intensification calls for further study of emotions in situations in which they become intensified, such as during mathematical challenges.

Many emotions, mainly positive ones, were noted as typical when experiencing mathematical challenges.

The most prominent qualitative and quantitative finding was that determination and curiosity were the dominant emotions, both in the number of participants who chose them and in their attributed intensity. The extraordinary dominance of these emotions corresponds with the relatively new term in educational psychology_-"grit" (Duckworth, Peterson, Matthews, \& Kelly 2007; Duckworth \& Gross, 2014). Duckworth was a math teacher for many years and after receiving psychology training, researched the phenomenon she had experienced as a teacher: that innate abilities are not the only, or even the main, component in mathematics success. In her study, she attempted to understand, from the students' perspective, which central factors contribute to mathematics achievement. Students were found to perceive determination, curiosity, and long-term persistence as more important than innate abilities. Grit, which indicates determination and persistence in striving to attain goals, is the dominant factor in facilitating coping with challenges. The central role of grit, as expressed in the present study, is consistent with the theory of goal-directed behavior (Ryan \& Deci, 2000; 2013; Meyer \& Turner, 2006), which sees goalsetting as an important component of coping with challenges in general.

The findings of our study correspond with the idea of positive emotions as a vital component in fostering well-being. They shed new light on the connection between mathematics and emotions, and stress the importance of positive emotions, which broaden the thought repertoire, encourage creativity, and are a key to flourishing.

Thus, our research might offer useful tools for math educators that can 
help improve attitudes toward mathematics. It encourages math educators to create a positive atmosphere and to search for new ways to develop the quality of grit in students; unlike innate mathematical talent, grit is a skill that can be learned and mastered.

\section{Acknowledgments}

We would like to thank Michlalah Jerusalem College for supporting our research, the Inter-Collegiate Research Committee in the MOFET institute, and the IIMCG participants for their cooperation.

\section{References}

Barrett, L. F., \& Russell, J. A. (1998). Independence and bipolarity in the structure of current affect. Journal of Personality and Social Psychology, 74(4), 967-984. http://dx.doi.org/10.1037/0022-3514.74.4.967.

Buck, R. (1999). The biological affects: A typology. Psychological Review 106(2), 301-336. http://dx.doi.org/10.1037//0033-295x.106.2.301.

Cooke, A., Kavussanu, M., McIntyre, D., \& Ring, C. (2013). The effects of individual and team competitions on performance, emotions, and effort. Journal of Sport \& Exercise Psychology, 35, 132-143.

Corbin, J., \& Strauss, A. (2007). Basics of qualitative research: Techniques and procedures for developing grounded theory, 4th ed. Thousand Oaks, CA: Sage.

Creswell, J. W. (2013). Research design: Qualitative, quantitative, and mixed methods approaches (4th ed.). Thousand Oaks, CA: Sage. http://dx.doi.org/10.1111/00440124.00746

DeBellis, V.A., \& Goldin, G.A. (1997). The affective domain in mathematical problem solving. In Pehkonen, E. (Ed.), Proceedings of the Twenty-first Annual Meeting of the International Group for the Psychology of Mathematics Education (pp. 209- 216). Lahti, Finland: University of Helsinki.

Deutsch, Z., \& Greensfeld, H. (2016). The "positive ratio" as a tool to measure positive emotions while coping with mathematical challenges. Paper presented at the 4th Jerusalem Conference on Research in Mathematics Education, held at the Jerusalem College of Technology, Israel.

Diener, E., Sandvik, E., Pavot, W. (1991). Happiness is the frequency, not the intensity, of positive versus negative affect. In F. Strack (Ed.), Subjective wellbeing: An interdisciplinary perspective (pp. 119-139). England, Oxford: Pergamon Press.

Di Martino, P., Zan, R. (2010). 'Me and maths': Towards a definition of attitude grounded on students' narratives. Journal of Mathematics Teacher Education, 13(1), 27-48. http://dx.doi.org/10.1007/s10857-009-9134-z.

Di Martino, P., \& Zan, R. (2011). Attitude towards mathematics: A bridge between beliefs and emotions. ZDM, 43(4), 471 - 482. Retrieved from http://bit.ly/2aCVgvX.

Domino, J. (2009). Teachers' influences on students' attitudes toward mathematics. Research and Teaching in Developmental Education, 26(1), 32-54. 
Duckworth, A. L., Peterson, C., Matthews, M. D., \& Kelly, D. R., (2007). Grit: Perseverance and Passion for Long-Term Goals. Journal of Personality and Social Psychology, 92(6), 1087-1101 http://dx.doi.org/10.1037/0022-3514.92. $\underline{6.1087 .}$

Duckworth, A. L., \& Gross, J. J. (2014). Self-Control and grit: Related but separable determinants of success. Current Directions in Psychological Science, 23(5), 319-325. http://dx.doi.org/ 10.1177/0963721414541462.

Fan, X., \& Chen, M. (2001). Parental involvement and students' academic achievement: A meta-analysis. Educational Psychology Review, 13, 27-61.

Fredrickson, B. L. (2001). The role of positive emotions in positive psychology: The broaden-and-build theory of positive emotions. American Psychologist, 56, 218226. http://dx.doi.org/10.1037/0003-066x.56.3.218.

Fredrickson, B. L. (2013). Updated thinking on positivity ratios. American Psychologist 68(9), 814-22. http://dx.doi.org/10.1037/a0033584.

Fredrickson, B. L., \& Branigan, C. (2005). Positive emotions broaden the scope of attention and thought-action repertoires. Cognition and Emotion, 19(3), 313-332. http://dx.doi.org/10.1080/02699930441000238.

Fredrickson, B. L., \& Losada M. F. (2005). Positive affect and the complex dynamics of human flourishing. American Psychologist, 60(7),678-686.

Frenzel, A. C., Pekrun, R., \& Goetz, T. (2007). Girls and Mathematics - A "hopeless" issue? A control-value approach to gender differences in emotions towards mathematics. European Journal of Psychology of Education, 22(4), 497-514. http://dx.doi.org/10.1007/bf03173468.

Goetz, T., Frenzel, A. C., Hall, N. C., \& Pekrun, R. H. (2008). Antecedents of academic emotions: Testing the internal/external frame of reference model for academic enjoyment. Contemporary Educational Psychology, 33(1), 9-33. http://dx.doi.org/10.1016/j.cedpsych.2006.12.002.

Hannula, M. S. (2002). Attitude towards mathematics: emotions, expectations and values. Educational Studies in Mathematics 49(1), 25-46. http://dx.doi.org/ 10.1023/a:1016048823497.

Hannula, M. S. (2006). Motivation in mathematics: Goals reflected in emotions. Educational Studies in Mathematics, 63(2), 165-178. http://dx.doi.org/10.1007/ s10649-005-9019-8.

Hannula, M. S. (2012). Exploring new dimensions of mathematics-related affect: Embodied and social theories. Research in Mathematics Education, 14(2), 137161. http://dx.doi.org/10.1080/14794802.2012.694281.

Johnson, J. M. (2002). In-Depth Interviewing. In J. F. Gubriom \& J. A. Holstein (Eds.), Handbook of Interview Research Context \& Method (pp. 103-119). London: Sage.

Lazarus, R. S. (2000). How emotions influence performance in competitive sports. The Sport Psychologist, 14, 229-252.

Linnenbrink, E. A. (2006). Emotion research in education: Theoretical and methodological perspectives on the integration of affect, motivation, and cognition. Educational Psychology Review, 18(4), 307-314. doi:10.1007/s10648006-9028-x.

Linnenbrink-Garcia, L., \& Pekrun, R. (2011). Students' emotions and academic engagement. Contemporary Educational Psychology, 36(1), 1-3. doi:10.1016/ j.cedpsych.2010.11.004.

Mandler, G. (1989). Affect and Learning: Causes and consequences of emotional interactions. In D. B. McLeod \& V.M. Adams (Eds.), Affect and mathematical problem solving: A new perspective (p. 3-19). New York: Springer-Verlag. http:// 
dx.doi.org/10.1007/978-1-4612-3614-6_1.

Martinent, G., Campo, M., \& Ferrand, C, (2012). A descriptive study of emotional process during competition: Nature, frequency, direction, duration and cooccurrence of discrete emotions. Psychology of Sport and Exercise, 13, 142-151.

Mata, M. D. L., Monteiro, V., \& Peixoto, F. (2012). Attitudes towards mathematics: Effects of individual, motivational, and social support factors. Child Development Research, 2012. http://dx.doi.org/10.1155/2012/876028.

Mauss, I. B., \& Robinson, M. D. (2009). Measures of emotion: A review. Cognition \& Emotion, 23(2), 209-237. http://dx.doi.org/10.1080/02699930802204677.

McLeod, D. B. (1992). Research on affect in mathematics education: A reconceptualisation. In D. A. Grouws (Ed.), Handbook of research on mathematics learning and teaching (pp. 575-596). New York, NY: Macmillan. http://dx.doi.org/10.2307/749568.

Meyer, D. K., \& Turner, J. C. (2006). Re-conceptualizing emotion and motivation to learn in classroom contexts. Educational Psychology Review, 18(4), 377-390.

Mohamed, L., \& Waheed, H. (2011). Secondary students' attitude towards mathematics in a selected school of Maldives. International Journal of Humanities and Social Science, 1(15), 277-281.

Muñoz-Merino, P. J., Molina, M. F., Muñoz-Organero, M., \& Kloos, C. D. (2014). Motivation and emotions in competition systems for education: An empirical study. IEEE Transactions on Education, 57(3), 182-187. http://dx.doi.org/10. 1109/TE.2013.2297318.

Ortony, A., \& Turner, T. J. (1990). What's basic about basic emotions? Psychological Review, 97(3), 315-331. http://dx.doi.org/10.1037//0033-295x.97.3.315.

Parrott, W. G. (2001). Emotions in social psychology: Volume overview. In W. G. Parrott (Ed.), Emotions in Social Psychology (p. 1-19). Philadelphia, PA: Psychology Press. http://dx.doi.org/10.4135/9781446221952.n1.

Pavot, W., \& Diener, E. (2013). Happiness experienced: The science of subjective well-being. The Oxford handbook of happiness. In S. A. David, I. Boniwell, \& A. C. Ayers (Eds.), The Oxford Handbook of Happiness (pp. 134-151). England, Oxford: Oxford University Press.

Pekrun, R., Goetz, T., Titz, W., \& Perry, R. (2002). Academic emotions in students' self-regulated learning and achievement: A program of qualitative and quantitative research. Educational Psychologist, 37(2), 91-105. doi:10.1037/00220663.98.3.583.

Rösken, B., Hannula, M. S., \& Pehkonen, E. (2011). Dimensions of students' view of themselves as learners of mathematics. ZDM - International Journal of Mathematics Education, 43, 497-506. http://dx.doi.org/10.1007/s11858-0110315-8.

Russell, J. A. (1980). A circumplex model of affect. Journal of Personality and Social Psychology, 39(6), 1161-1178. http://dx.doi.org/10.1037/h0077714.

Ryan, R. M. \& Deci, E. L. (2000). When rewards compete with nature: The undermining of intrinsic motivation and self-regulation. In C. Sansone \& J.M. Harackiewicz (eds.), Intrinsic and extrinsic motivation: The search for optimal motivation and performance (pp. 13-55). San Diego, CA: Academic Press. http://dx.doi.org/10.1016/b978-012619070-0/50024-6.

Ryan, R. M., \& Deci, E. L. (2013). Toward a social psychology of assimilation: Selfdetermination theory in cognitive development and education. In B. W. Sokol, F. M. E. Grouzet, U. Muller (Eds.), Self-regulation and autonomy: Social and developmental dimensions of human conduct (pp. 191-207). Cambridge, England: Cambridge University Press. http://dx.doi.org/10.1017/CBO9781139152198.014. 
Ryen, A. (2002). Cross-cultural interviewing. In J. F. Gubriom \& J. A. Holstein (Eds.), Handbook of Interview Research Context \& Method (pp. 335-334). London: Sage.

Singh, K., Granville, M., \& Dika, S. (2002). Mathematics and science achievement: Effects of motivation, interest, and academic engagement. The Journal of Educational Research, 95(6), 323-332. Retrieved from http://bit.ly/2a997ba.

Soni, A., \& Kumari, S. (2015). The role of parental Math attitude in their children Math achievement. International Journal of Applied Sociology, 5(4), 159-163.

Taylor, P. (2009). WFNMC 25 years on: Some experiences. Mathematics Competitions, 22(1), 10-18.

van Voorhis, F. L., Maier, M. F., Epstein, J. L., \& Lloyd, C. M. (2013). The impact of family involvement on the education of children ages 3 to 8: A focus on literacy and Math achievement outcomes and social-emotional skills. MDRC, Building knowledge to improve social policy. Retrieved from http://bit.ly/1nkjVDz.

Watson, D., Clark, L. A. \& Tellegen, A. (1988). Development and validation of brief measures of positive and negative affect: The PANAS scale. Journal of Personality and Social Psychology, 54(6), 1063-1070. http://dx.doi.org/10.1037/ 0022-3514.54.6.1063.

Weiner, B. (1985). An attributional theory of achievement motivation and emotion. Psychological Review, 92(4), 548-573. http://dx.doi.org/10.1037/0033-295X. 92.4.548.

Zan, R., Brown, L., Evans, J., \& Hannula, M. S. (2006). Affect in mathematics education: An introduction. Educational Studies in Mathematics, 63(2), 113-121. http://dx.doi.org/10.1007/s10649-006-9028-2. 
